\title{
PENGARUH PENERAPAN MODEL PEMBELAJARAN BERBASIS MASALAH TERHADAP KEMAMPUAN BERPIKIR KREATIF MATEMATIS SISWA KELAS VIII SMP NEGERI 4 KENDARI
}

\author{
Sitti Nur Astuti ${ }^{I)}$, Muhammad Sudia ${ }^{2)}$,Utu Rahim ${ }^{3)}$ \\ ${ }^{1)}$ Alumni Jurusan Pendidikan Matematika, ${ }^{2,3)}$ Dosen Jurusan Pendidikan Matematika \\ FKIP Universitas Halu Oleo email: stnurastuti.s@gmail.com; \\ muhammad_matematika@yahoo.co.id; uturahim56@gmail.com
}

\begin{abstract}
Abstrak
Penelitian ini dilatar belakangi oleh rendahnya kemampuan berpikir kreatif matematis siswa. Penelitian ini merupakan penelitian eksperimen semu One Group Pretest-Posttest Design. Populasi dalam penelitian ini adalah seluruh siswa kelas VIII SMP Negeri 4 Kendari yang terdiri dari 11 kelas paralel. Teknik pengambilan sampel dalam penelitian ini dilakukan secara simple random sampling. Data diperoleh menggunakan lembar observasi dan instrumen berupa tes kemampuan berpikir kreatif matematis. Berdasarkan hasil analisis data dan pembahasan diperoleh kesimpulan: (1) kemampuan berpikir kreatif matematis siswa sebelum diajar dengan model pembelajaran berbasis masalah memiliki nilai rata - rata 39,01. Varians dan std. deviasi masing-masing sebesar 310,13 dan 17,61; (2) kemampuan berpikir kreatif matematis siswa setelah diajar dengan model pembelajaran berbasis masalah memiliki nilai rata - rata 48,86. Varians dan std. deviasi masing-masing sebesar 533,33 dan 23,09; (3) model pembelajaran berbasis masalah memberikan pengaruh signifikan terhadap kemampuan berpikir kreatif matematis siswa kelas VIII SMP Negeri 4 Kendari.
\end{abstract}

Kata Kunci : model pembelajaran berbasis masalah, kemampuan berpikir kreatif matematis

\section{THE EFFECTS OF THE APPLICATION PROBLEM-BASED LEARNING MODELS TOWARDS MATHEMATICAL CREATIVE THINKING ABILITY OF GRADE VIII STUDENTS OF SMP NEGERI 4 KENDARI}

\begin{abstract}
This research was motivated by the low of the ability of mathemathical creative thinking of students. This research is a quasi-experimental study of One Group Pretest-Posttest Design. The population in this study were all $8^{\text {th }}$ grade students on SMP Negeri 4 Kendari which consisted of 11 parallel classes. The sampling technique in this study was done by using simple random sampling. Data were obtained using observation sheets and instruments in the form of tests of mathematical creative thinking ability. Based on the results of data analysis and discussion concluded: (1) the average of mathematical creative thinking ability of students before taught by problem-based learning models is 39,01 . The varians also the std. deviations sequentially 310,13 and 17,61 ; (2) the average of mathematical creative thinking ability of students after taught by problem-based learning models is 48,86. The varians also the std. deviations sequentially 533,33 and 23,09; (3) the problem-based learning models was had significantly effect to the mathematical creative thinking ability of $8^{\text {th }}$ grade students of SMP Negeri 4 Kendari.
\end{abstract}

Keywords: Problem-based learning models, mathematical creative thinking ability. 


\section{Pendahuluan}

Masa depan suatu bangsa sangat bergantung pada mutu sumber daya manusianya dan kemampuan peserta didiknya untuk menguasai ilmu pengetahuan dan teknologi. Oleh karena itu, sumber daya manusia menjadi aset negara yang cukup besar peranannya dalam menata kehidupan bangsa. Untuk meningkatkan kualitas SDM maka dibutuhkan pendidikan. Hal ini dikarenakan pendidikan berfungsi sebagai sebuah proses dimana seseorang dididik agar dapat memiliki kualitas moral dan keahlian yang nantinya akan berguna bagi kemajuan negara ini. Di Indonesia, pendidikan bertujuan untuk mengembangkan potensi peserta didik agar menjadi manusia yang beriman dan bertakwa pada Tuhan Yang Maha Esa, berakhlak mulia, sehat, berilmu, cakap, kreatif, mandiri, dan menjadi warga negara yang demokratis dan bertanggungjawab.

Salah satu alat untuk mencapai tujuan pendidikan adalah kurikulum. Kurikulum 2013 adalah kurikulum yang saat ini sedang berlaku di Indonesia. Dalam pelaksanaannya, pendekatan pembelajaran yang wajib digunakan dalam kurikulum 2013 adalah pendekatan saintifik. Pendekatan saintifik pada pembelajaran bertujuan meningkatkan kemampuan intelek, khususnya kemampuan berpikir tingkat tinggi (higher order thinking). Salah satu karakteristik berpikir tingkat tinggi adalah berpikir kreatif. Oleh karena itu, dalam proses belajar mengajar diperlukan timbul dan berkembangnya kompetensi pengembangan berpikir kreatif dalam diri peserta didik. Kemampuan berpikir kreatif pula sangat penting dalam memecahkan permasalahan yang ada dalam kehidupan bermasyarakat, sebab masalah-masalah yang dijumpai di masyarakat merupakan masalah yang sangat kompleks dan membutuhkan ide ide kreatif dalam pemecahannya.

Model pembelajaran yang dapat mempengaruhi kemampuan berpikir kreatif adalah model pembelajaran yang dapat mengaktifkan siswa, melatih siswa untuk menemukan sendiri solusi suatu masalah dari berbagai sudut pandang. Dengan melatih siswa untuk lebih mandiri dalam memecahkan masalah maka dapat melatih kemampuan berpikir mereka. Hasilnya siswa mampu membentuk pengetahuannya sendiri dan kreatif dalam menjawab tantangan yang ada. Salah satu model pembelajaran yang memenuhi kriteria tersebut adalah Problem Based Learning atau pembelajaran berbasis masalah.

Pembelajaran berbasis masalah adalah seperangkat model mengajar yang menjadikan masalah sebagai fokus untuk mengembangkan keterampilan siswa dalam memecahkan masalah. Pembelajaran berbasis masalah menuntut siswa untuk aktif melalui proses mengumpulkan dan menganalisis informasi dari berbagai sumber dengan tujuan untuk dapat memecahkan masalah yang dihadapinya.

Pembelajaran berbasis masalah mampu mengembangkan kemampuan berpikir kreatif siswa juga didukung oleh pendapat Tan (Sucipto, 2017: 68) yang menegaskan bahwa perkembangan kecerdasan dalam pemecahan masalah dan kompetensi untuk pemecahan masalah secara kreatif merupakan tujuan penting dari PBL.

Suprihatiningrum (2011: 215) menjelaskan bahwa pembelajaran berbasis masalah adalah suatu model pembelajaran, yang mana siswa sejak awal dihadapkan pada suatu masalah, kemudian diikuti oleh proses pencarian informasi yang bersifat student centered. Pembelajaran berbasis masalah dipusatkan pada siswa yang dihadapkan pada suatu masalah, bertujuan agar siswa mampu memperoleh dan membentuk pengetahuannya secara efisien, kontekstual, dan terintegrasi. Model pembelajaran pokok, dalam pembelajaran berbasis masalah berupa belajar dalam kelompok kecil dengan sistem tutorial.

Menurut Finkle dan Torp (Shoimin, 2014: 130) pembelajaran berbasis masalah merupakan pengembangan kurikulum dan sistem pengajaran yang mengembangkan secara simultan strategi pemecahan masalah dan dasardasar pengetahuan dan keterampilan dengan menempatkan para peserta didik dalam peran aktif sebagai pemecah masalah sehari-hari yang tidak terstruktur dengan baik.

Pembelajaran berbasis masalah mempunyai karakteristik pembelajaran yang membedakannya dengan pembelajaran yang lain. Menurut Arends (Wahyuningsih, 2012: 3334), berbagai pengembangan pengajaran berdasarkan masalah telah memberikan karakteristik PBL sebagai berikut:

1) Pengajuan pertanyaan atau masalah. PBL ini mengorganisasikan pengajaran di sekitar 
pertanyaan dan masalah yang dua-duanya secara sosial penting dan secara pribadi bermakna untuk peserta didik. Mereka mengajukan situasi kehidupan nyata autentik, menghindari jawaban sederhana, dan memungkinkan adanya berbagai macam solusi untuk situasi tersebut.

2) Berfokus pada keterkaitan antardisiplin.

3) Penyelidikan autentik. PBL mengharuskan peserta didik melakukan penyelidikan autentik untuk mencari penyelesaian nyata terhadap masalah.

4) Menghasilkan produk dan memamerkannya.

5) Kolaborasi. PBL dicirikan dengan peserta didik yang bekerja sama satu dengan yang lainnya, paling sering secara berpasangan atau dalam kelompok kecil. Bekerja sama memberikan motivasi untuk secara berkelanjutan terlibat dalam tugas-tugas kompleks dan memperbanyak peluang untuk berbagi inkuiri dan dialog dan untuk mengembangkan keterampilan sosial dan keterampilan berpikir

Sean dan Hersh (Permana \& Sumarmo, 2007: 118) mengemukakan beberapa karakteristik PBM yaitu: (a) Masalah harus berkaitan dengan kurikulum, (b) Masalah bersifat tak terstruktur, solusi tidak tunggal, dan prosesnya bertahap, (c) Siswa memecahkan masalah dan guru sebagai fasilitator, (d) Siswa hanya diberi panduan untuk mengenali masalah, dan tidak diberi formula untuk memecahkan masalah, dan (e) Penilaian berbasis performa autentik Pierce dan Jones mengklasifikasi PBM dalam dua level yaitu level rendah dan level tinggi. PBM tergolong pada level rendah jika hanya memuat sedikit karakteristik di atas, dan PBM tergolong pada level tinggi jika siswa terlibat secara aktif dalam kegiatan-kegiatan yang mencerminkan karakteristik PBM di atas.

Herman (2007: 48) menyatakan bahwa karakteristik dari Pembelajaran berbasis masalah di antaranya adalah: 1) memposisikan siswa sebagai self-directed problem solver melalui kegiatan kolaboratif, 2) mendorong siswa untuk mampu menemukan masalah dan mengelaborasinya dengan mengajukan dugaandugaan dan merencanakan penyelesaian, 3) memfasilitasi siswa untuk mengeksplorasi berbagai alternative penyelesaian dan implikasinya, serta mengumpulkan dan mendistribusikan informasi, 4) melatih siswa untuk terampil menyajikan temuan, dan 5) membiasakan siswa untuk merefleksi tentang efektivitas cara berpikir mereka dalam menyelesaikan masalah. Untuk langkah-langkah model pembelajaran berbasis masalah secara ringkas dapat dilihat dalam tabel 1 berikut ini

Tabel 1

Langkah-Langkah Model Pembelajaran Berbasis Masalah

\begin{tabular}{|c|l|l|}
\hline Fase & \multicolumn{1}{|c|}{ Indikator } & \multicolumn{1}{c|}{ Tingkah Laku Guru } \\
\hline 1 & $\begin{array}{l}\text { Orientasi siswa pada } \\
\text { masalah }\end{array}$ & $\begin{array}{l}\text { Menjelaskan tujuan pembelajaran, menjelaskan logistik yang } \\
\text { diperlukan dan memotivasi siswa terlibat pada aktivitas } \\
\text { pemecahan masalah. }\end{array}$ \\
\hline 2 & $\begin{array}{l}\text { Mengorganisasikan siswa } \\
\text { untuk belajar }\end{array}$ & $\begin{array}{l}\text { Membantu siswa mendefinisikan dan mengorganisasikan } \\
\text { tugas belajar yang berhubungan dengan masalah tersebut. }\end{array}$ \\
\hline 3 & $\begin{array}{l}\text { Membimbing pengalaman } \\
\text { individual atau kelompok }\end{array}$ & $\begin{array}{l}\text { Mendorong siswa untuk mengumpulkan informasi yang } \\
\text { sesuai, melaksanakan eksperimen untuk mendapatkan } \\
\text { penjelasan dan pemecahan masalah. }\end{array}$ \\
\hline 4 & $\begin{array}{l}\text { Mengembangkan dan } \\
\text { menyajikan hasil karya }\end{array}$ & $\begin{array}{l}\text { Membantu siswa dalam merencanakan dan menyiapkan karya } \\
\text { yang sesuai seperti laporan dan membantu mereka untuk } \\
\text { berbagi tugas dengan temannya. }\end{array}$ \\
\hline 5 & $\begin{array}{l}\text { Menganalisis dan } \\
\text { mengevaluasi proses } \\
\text { pemecahan masalah }\end{array}$ & $\begin{array}{l}\text { Membantu siswa untuk melakukan refleksi atau evaluasi } \\
\text { terhadap penyelidikan mereka dan proses yang mereka } \\
\text { gunakan. }\end{array}$ \\
\hline
\end{tabular}

Sumber: Rusman (2012: 243)

Shoimin (2014: 132) menyatakan bahwa pembelajaran berbasis masalah memiliki delapan kelebihan, yaitu:
1. Siswa didorong untuk memiliki kemampuan memecahkan masalah dalam situasi nyata. 
2. Siswa memiliki kemampuan membangun pengetahuannya sendiri melalui aktivitas belajar.

3. Pembelajaran berfokus pada masalah sehingga materi yang tidak ada hubungannya tidak perlu dipelajari oleh siswa. Hal ini mengurangi beban siswa dengan menghafal atau menyimpan informasi.

4. Terjadi aktivitas ilmiah pada siswa melalui kerja kelompok.

5. Siswa terbiasa menggunakan sumbersumber pengetahuan, baik dari perpustkaan, internet, wawancara, dan observasi.

6. Siswa memiliki kemampuan menilai kemajuan belajarnya sendiri.

7. Siswa memiliki kemampuan untuk melakukan komunikasi ilmiah dalam kegiatan diskusi atau prensentasi hasil pekerjaan mereka.

8. Kesulitan belajar siswa secara individual dapat diatasi melalui kerja kelompok dalam bentuk peer teaching.

Adapun kelemahan pembelajaran berbasis masalah menurut Sanjaya (2007: 220) yaitu: (1) memerlukan waktu yang panjang dibandingkan dengan model pembelajaran yang lain, (2) manakala peserta didik tidak memiliki minat atau memiliki kepercayaan bahwa masalah yang dipelajari sulit untuk dipecahkan, maka akan merasa enggan untuk mencoba.

Berpikir adalah suatu kegiatan mental yang melibatkan kerja otak untuk memahami sesuatu yang dialami atau mencari jalan keluar dari persoalan yang sedang dihadapi. Para ahli psikologi kognitif juga memandang berpikir merupakan kegiatan memproses informasi secara mental atau kognitif. Menurut Wibawa (2016: 19) proses berpikir memiliki delapan komponen utama, yaitu: (1) pembentukan konsep, (2) pembentukan prinsip, (3) pemahaman, (4) pemecahan masalah, (5) pengambilan keputusan, (6) penelitian, (7) penyusunan, dan (8) berwacana secara oral. Kedelapan komponen tersebut dapat digolongkan menjadi dua kategori yaitu pemerolehan pengetahuan (pembentukan konsep, pembentukan prinsip, pemahaman penelitian dan berwancan secara oral) dan produksi atau aplikasi pengetahuan (pemecahan masalah, pengambilan keputusan, penyusunan, penelitian, dan berwacana secara oral).

Salah satu jenis berpikir adalah berpikir kreatif. Johnson (Moma, 2015: 28), menyatakan bahwa berpikir kreatif yang mengisyaratkan ketekunan, disiplin pribadi, dan perhatian melibatkan aktivitas-aktivitas mental seperti mengajukan pertanyaan, mempertimbangkan informasi-informasi baru dan ide-ide yang tidak biasanya dengan suatu pikiran terbuka, membuat hubungan-hubungan, khususnya antara sesuatu yang serupa, mengaitkan satu dengan yang lainnya dengan bebas, menerapkan imajinasi pada setiap situasi yang membangkitkan ide baru dan berbeda, dan memperhatikan intuisi.

Berpikir kreatif merupakan salah satu tingkat tertinggi seseorang dalam berpikir. Untuk lebih jelasnya, tingkat berpikir disajikan pada gambar berikut.

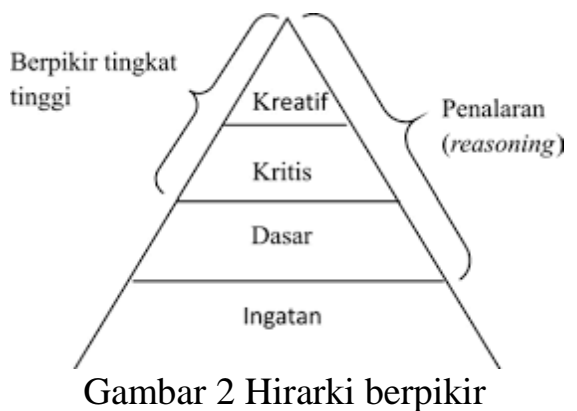

Sumber: Krulik \& Rudnik (Saefudin, 2012: 40)

Hamalik (Lambertus, Arapu, \& Patih, 2013: 74), menjelaskan bahwa aspek khusus berpikir kreatif adalah berpikir divergen (divergen think), yang memiliki ciri-ciri kelancaran (fluency), keluwesan (flexibility), keaslian (originality). Kelancaran (fluency) menunjuk pada kuantitas output, lebih banyak jawaban berarti lebih kreatif, keluwesan (flexibility) menggambarkan keragaman (devergensy) ungkapan atau sambutan terhadap suatu simulasi, keaslian (originality) menunujuk pada tingkat keaslian sejumlah gagasan, jawaban 
atau pendapat terhadap suatu persoalan. Guilfold menambahkan satu komponen selain dari kelancaran (fluency), keluwesan (flexibility), keaslian (originality) yaitu keterincian (elaboration). Dalam hal ini, ada empat komponen kunci yang dinilai dalam kreativitas. Komponen tersebut meliputi kelancaran (fluency), keluwesan (flexibility), keaslian (originality), dan keterincian (elaboration) dalam berpikir. Dari keempat komponen tersebut yang kemudian diadaptasi oleh beberapa ahli matematika dan digunakan sebagai indikator untuk menilai kemampuan berpikir kreatif matematis.

Khusus dalam matematika, Balka (Hendriana, Rohaeti dan Sumarmo, 2017: 113) menyatakan bahwa kemampuan berpikir kreatif matematis meliputi kemampuan berpikir konvergen dan berpikir divergen, yang dirinci menjadi: a) kemampuan memformulasi hipotesis matematika yang difokuskan pada sebab dan akibat dari suatu situasi masalah matematis, b) kemampuan untuk menentukan pola-pola yang ada dalam situasi-situasi masalah matematis, c) kemampuan memecahkan kebuntuan pikiran dengan mengajukan solusi-solusi baru dari masalah matematis, d) kemampuan mengemukakan ide-ide matematika yang tidak biasa dan dapat mengevaluasi konsekuensikonsekuensi yang ditimbulkannya, e) kemampuan mengidentifikasi informasi matematis yang hilang dari masalah yang diberikan, dan f) kemampuan merinci masalah yang lebih spesifik.

\section{Metode}

Penelitian ini termasuk dalam jenis penelitian eksperimen semu yang mengukur

Tabel 2

Desain Penelitian

\begin{tabular}{|c|c|c|}
\hline Pretest & Treatment & Posttest \\
\hline $\mathrm{O}_{1}$ & $\mathrm{X}$ & $\mathrm{O}_{2}$ \\
\hline
\end{tabular}

Keterangan:

$\mathrm{O}_{1}=$ Tes kemampuan berpikir kreatif matematis siswa sebelum diajar dengan menggunakan model pembelajaran berbasis masalah.

$\mathrm{O}_{2}=$ Tes kemampuan berpikir kreatif matematis siswa setelah diajar dengan menggunakan model pembelajaran berbasis masalah. kemampuan berpikir kreatif matematis dengan menggunakan model pembelajaran berbasis masalah pada kelas eksperimen dengan pokok bahasan sistem persamaan linear dua variabel kelas VIII SMP Negeri 4 Kendari.

Populasi dalam penelitian ini adalah seluruh siswa kelas VIII SMP Negeri 4 Kendari tahun ajaran 2018/2019 semester 1 yang terdistribusi dalam 11 kelas, yaitu kelas $\mathrm{VIII}_{1}$, $\mathrm{VIII}_{2}, \mathrm{VIII}_{3}, \mathrm{VIII}_{4}, \mathrm{VIII}_{5}, \mathrm{VIII}_{6}, \mathrm{VIII}_{7}, \mathrm{VIII}_{8}, \mathrm{VIII}_{9}$, $\mathrm{VIII}_{10}, \mathrm{VIII}_{11}$.

Pengambilan sampel dilakukan dengan menggunakan teknik simple random sampling. Sampel yang dibutuhkan dalam penelitian adalah sebanyak satu kelas. Berdasarkan teknik pengambilan sampel tersebut, diperoleh kelas $\mathrm{VIII}_{9}$, dengan jumlah siswa 34 siswa (19 lakilaki dan 15 perempuan) sampel penelitian.

Variabel yang digunakan dalam penelitian ini terdiri dari satu variabel bebas $(X)$ dan satu variabel terikat $(Y)$.

a. Variabel bebas (independen) yaitu pembelajaran matematika dengan menggunakan model pembelajaran berbasis masalah $(X)$.

b. Variabel terikat (dependen) yaitu kemampuan berpikir kreatif matematis siswa setelah dilakukan pembelajaran dengan menggunakan model pembelajaran berbasis masalah $(Y)$.

Desain penelitian yang digunakan adalah One group pretest-posttest design. Sebelum melakukan penelitian kelompok sampel diberikan pretest dan setelah dilakukan penelitian kelompok sampel akan diberikan posttest. Prosedurnya seperti digambarkan pada tabel berikut:

$\mathrm{X}=$ Perlakuan pembelajaran dengan model pembelajaran berbasis masalah.

Instrumen dalam penelitian ini berupa lembar observasi dan instrumen tes kemampuan berpikir kreatif matematis siswa. Lembar observasi digunakan untuk mengukur efektivitas pembelajaran matematika dengan menggunakan model pembelajaran berbasis masalah. Lembar observasi ini diisi oleh 
observer saat mengamati secara langsung keterlaksanaan pembelajaran yang dilakukan oleh guru dan siswa saat pembelajaran tengah berlangsung. Untuk mengukur kemampuan berpikir kreatif matematis siswa digunakan tes tertulis berbentuk uraian (essay) sebanyak empat nomor untuk pretest pada materi yang telah dipelajari oleh siswa, yaitu materi persamaan linear satu variabel dan empat nomor untuk posttest pada materi yang diteliti, yaitu materi SPLDV. Sebelum soal-soal tes ini digunakan, terlebih dahulu peneliti mengujicobakannya untuk mengetahui validitas dan reliabilitas soal tes.

Untuk mendapatakan validitas soal tes dalam penelitian ini, peneliti menggunakan validitas konstruksi dan validitas empiris. Hasil validitas konstruksi ditentukan oleh penilaian para ahli yang terdiri dari dua orang dosen pendidikan matematika FKIP UHO dan 1 orang guru matematika di SMP Negeri 4 Kendari. Setelah validitas konstruksi, maka dilakukan uji coba tes kepada 31 siswa kelas VIII $_{\mathrm{A}}$ SMP Negeri 2 Kendari untuk pretest dan 29 siswa kelas IX $_{\mathrm{G}}$ SMP Negeri 5 Kendari untuk posttest.

Tabel 3

Data Hasil Pretest dan Posttest

\begin{tabular}{|c|c|c|}
\hline Data & Pretest & Postest \\
\hline Jumlah Sampel & 34 & 34 \\
\hline Rata-Rata & 39,01 & 48,86 \\
\hline Median & 43,75 & 50 \\
\hline Modus & 50 & 62,5 \\
\hline Standar Deviasi & 17,61 & 23,09 \\
\hline Varians & 310,13 & 533,33 \\
\hline Nilai Minimum & 6,25 & 12.5 \\
\hline Nilai Maksimum & 75 & 100 \\
\hline
\end{tabular}

Dari tabel di atas dapat dilihat pada pretest bahwa 6,25 sebagai nilai terendah, hal ini menunjukan bahwa terdapat siswa yang belum memahami materi persamaan linear satu variabel yang disajikan dalam bentuk soal berpikir kreatif matematis. Nilai tertinggi yang diperoleh oleh siswa adalah 75 yang berarti bahwa terdapat siswa yang sudah cukup memahami materi persamaan linear satu variabel yang disajikan dalam bentuk soal berpikir kreatif matematis. Rata-rata nilai yang diperoleh pada pretest sebesar 39,01. Bila dibandingkan dengan nilai maksimal sebesar 100 maka hasil yang diperoleh pada tes awal menggambarkan bahwa secara keseluruhan kemampuan awal berpikir kreatif
Reliabilitas menunjuk pada suatu pengertian bahwa suatu instrumen dapat dipercaya untuk digunakan sebagai alat pengumpul data.

Analisis data dalam penelitian ini menggunakan analisis deskriptif dan analisis inferensial. Analisis deskriptif merupakan analisis yang digunakan untuk menggambarkan keadaan sampel dalam bentuk persentase (\%), rata-rata $(\overline{\mathrm{x}})$, median $(\mathrm{Me})$, modus $(\mathrm{Mo})$, standar deviasi $(\mathrm{s})$, varians $\left(\mathrm{s}^{2}\right)$, nilai minimum $\left(\mathrm{x}_{\mathrm{min}}\right)$, dan nilai maksimum ( $\left.\mathrm{x}_{\text {maks }}\right)$. Sedangkan analisis inferensial dimaksudkan untuk menguji hipotesis penelitian, namun terlebih dahulu melalui tahapan yang lain, yaitu uji normalitas sebagai prasyarat untuk pengujian hipotesis.

\section{Hasil}

Setelah dilakukan uji validitas dan reliabilitas, instrument yang dinyatakan valid pun diberikan pada sampel penelitian. Kemudian dilakukan pengolahan data nilai pretest dan posttest pada kelas eksperimen yang disajikan hasil statistik deskriptif data sebagai berikut: matematis siswa di kelas eksperimen tergolong masih kurang, yang artinya kemampuan berpikir kreatif siswa tersebut masih harus ditingkatkan. Median (nilai tengah) pada pretest sebesar 43,75. Modus (nilai yang sering muncul) yaitu 50. Nilai ini menunjukan bahwa sebagian besar siswa memiliki tingkat kemampuan berpikir kreatif matematis yang tergolong cukup.

Berdasarkan hasil analisis deskriptif pada tabel 4.1 dapat dilihat pada posttest bahwa 12,5 sebagai nilai terendah, yang artinya setelah diterapkan model pembelajaran berbasis masalah masih terdapat siswa yang kemampuan berpikir kreatif matematisnya tergolong tidak kreatif pada materi sistem persamaan linear dua variabel. Meskipun demikian, kemampuan 
berpikir kreatif matematis siswa setelah diberikan pembelajaran berupa model pembelajaran berbasis masalah mengalami peningkatan. Nilai tertinggi pada data hasil posttest adalah 100. Nilai ini menunjukan bahwa terdapat siswa yang memiliki kemampuan berpikir kreatif matematis yang tergolong sangat baik atau sangat kreatif. Siswa tersebut sudah dapat dikatakan telah mampu menguasai empat indikator kemampuan berpikir kreatif matematis. Nilai rata-rata yang diporeh dari posttest adalah 48,86 , yang menunjukan secara keseluruhan kemampuan berpikir kreatif matematis siswa tergolong cukup, artinya secara keseluruhan kemampuan berpikir kreatif matematis siswa setelah diterapkan model pembelajaran berbasis masalah mengalami peningkatan dibanding sebelumnya, namun masih perlu ditingkatkan lagi. Median (nilai tengah) pada data posttest sebesar 50. Modus (nilai yang sering muncul) yaitu 62,5. Nilai ini menunjukan bahwa sebagai besar siswa memiliki tingkat berpikir kreatif matematis yang baik. Hal ini semakin mempertegas bahwa setelah pembelajaran dengan menggunakan model pembelajaran berbasis masalah, sebagian besar kemampuan berpikir kreatif matematis siswa telah meningkat dibanding sebelum diberikan perlakuan.

Adapun Standar deviasi (simpangan baku) dan varians pada pretest secara beturutturut diperoleh 17,61 dan 310,13 serta pada posstest diperoleh 23,09 dan 533,33. Nilai varians dari kedua data tersebut menunjukkan bahwa kemampuan berpikir kreatis matematis siswa setelah pembelajaran lebih beragam daripada sebelum pembelajaran dengan model pembelajaran berbasis masalah.

Deskripsi kemampuan berpikir kreatif matematis siswa kelas VIII 9 SMP Negeri 4 Kendari ditinjau dari tingkat kreatifitas siswa sebelum dan sesudah diajar menggunakan model pembelajaran berbasis masalah ditampilkan pada tabel berikut:

Tabel 4

Distribusi Frekuensi Berdasarkan Interval Kelas Nilai Kemampuan Berpikir Kreatif Matematis Siswa

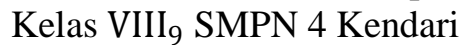

\begin{tabular}{|c|c|c|c|c|c|c|}
\hline \multirow[b]{2}{*}{ No. } & \multirow[b]{2}{*}{ Nilai } & \multicolumn{4}{|c|}{ Frekuensi $(f)$} & \multirow{2}{*}{$\begin{array}{c}\text { Tingkat } \\
\text { Kreativitas } \\
\text { Siswa }\end{array}$} \\
\hline & & Pretest & Persentase $(\%)$ & Posttest & Persentase $(\%)$ & \\
\hline 1 & $80<Y \leq 100$ & 0 & 0 & 5 & 14,7 & Sangat Kreatif \\
\hline 2 & $60<\mathrm{Y} \leq 80$ & 4 & 11,8 & 6 & 17,6 & Kreatif \\
\hline 3 & $40<Y \leq 60$ & 14 & 41,2 & 10 & 29.4 & Cukup Kreatif \\
\hline 4 & $20<\mathrm{Y} \leq 40$ & 9 & 26,5 & 8 & 23,5 & Kurang Kreatif \\
\hline 5 & $0 \leq \mathrm{Y} \leq 20$ & 7 & 20.6 & 5 & 14.7 & Tidak Kreatif \\
\hline
\end{tabular}

Berdasarkan tabel 4 tampak bahwa, sebelum dilaksanakan pembelajaran dengan model pembelajaran berbasis masalah kemampuan berpikir kreatif matematis siswa berada pada kategori kreatif, cukup kreatif, kurang kreatif, dan tidak kreatif. Pada pretest tidak ada satupun siswa yang berada pada kategori sangat kreatif. Berdasarkan hasil analisis tersebut, dapat disimpulkan bahwa kemampuan berpikir kreatif matematis siswa ditinjau dari data pretest tergolong cukup kreatif.

Setelah dilaksanakan pembelajaran dengan model pembelajaran berbasis masalah, kemampuan berpikir kreatif matematis siswa berada pada kategori sangat kreatif, kreatif, cukup kreatif, kurang kreatif, dan tidak kreatif. Berbeda dengan hasil pretest dimana tidak seorangpun siswa yang berada pada kategori siswa yang berada pada kategori sangat kreatif. Selain itu, jumlah siswa yang berada pada kategori kreatif mengalami peningkatan dan jumlah siswa yang berada pada kategori cukup kreatif, kurang kreatif dan tidak kreatif mengalami penurunan. Berdasarkan hasil analisis tersebut, maka dapat disimpulkan bahwa kemampuan berpikir kreatif matematis siswa mengalami peningkatan setelah diajar dengan model pembelajaran berbasis masalah. Dengan kata lain, penerapan model pembelajaran berbasis masalah memberikan pengaruh positif terhadap perkembangan kemampuan berpikir kreatif matematis siswa.

Tingkat aktivitas guru selama lima kali pelaksanaan pembelajaran dengan menggunakan model pembelajaran berbasis masalah disajikan dalam tabel berikut: 
Tabel 5

Hasil Observasi Aktivitas Guru

\begin{tabular}{|c|c|c|c|}
\hline Pertemuan & Skor & Persentase (\%) & Kriteria \\
\hline $\mathbf{1}$ & 21 & $84 \%$ & Sangat Baik \\
\hline $\mathbf{2}$ & 22 & $88 \%$ & Sangat Baik \\
\hline $\mathbf{3}$ & 23 & $92 \%$ & Sangat Baik \\
\hline $\mathbf{4}$ & 23 & $92 \%$ & Sangat Baik \\
\hline $\mathbf{5}$ & 23 & $92 \%$ & Sangat Baik \\
\hline
\end{tabular}

Skor maksimal $=25$

Berdasarkan tabel tersebut, persentase keberhasilan pengelolaan pembelajaran pada pertemuan pertama mencapai $84 \%$. Pada pertemuan ini, guru masih melakukan penyesuaian terhadap tahap-tahap model pembelajaran berbasis masalah, demikian pula siswa baru mulai untuk beradaptasi dengan model pembelajaran berbasis masalah. Sehingga langkah-langkah pembelajaran yang direncanakan tidak dapat dilaksanakan, seperti guru tidak sempat mempersilahkan setiap perwakilan kelompok untuk mempresentasikan hasil kerja kelompoknya pada tahap mengembangkan dan menyajikan hasil karya akibat alokasi waktu pembelajaran telah habis.

Persentase keberhasilan pengelolaan pembelajaran pada pertemuan kedua, meningkat dari pertemuan pertama dan mencapai $88 \%$. Hal ini terjadi karena guru telah mengadakan refleksi terhadap pertemuan pertama, sehingga guru melaksanakan tahap - tahap pembelajaran dengan lebih terorganisir. Namun, pada pertemuan kedua ini, lagi-lagi seperti pada pertemuan pertama tahap mengembangkan dan menyajikan hasil karya tidak dapat terlaksana dengan maksimal akibat alokasi waktu pembelajaran telah habis. Hal ini sama seperti pada pertemuan ketiga, keempat dan kelima. Akan tetapi dalam pelaksanaannya untuk mengatasi hal tersebut, tiap pertemuan kelompok yang akan mempresentasikan hasil diskusi kelompoknya adalah kelompok yang berbeda.

Tingkat keaktifan siswa selama lima kali pelaksanaan pembelajaran dengan menggunakan model pembelajaran berbasis masalah dapat dilihat pada tabel 6 berikut:

Tabel 6

Deskripsi Aktivitas Siswa Selama Pembelajaran di Kelas VIII 9

\begin{tabular}{|c|c|c|}
\hline Pertemuan & Skor & Persentase (\%) \\
\hline Pertama & 62 & 49.6 \\
\hline Kedua & 79 & 63.2 \\
\hline Ketiga & 92 & 73.6 \\
\hline Keempat & 104 & 83.2 \\
\hline Kelima & 115 & 92 \\
\hline \multicolumn{2}{|c|}{ Rata-rata Persentase } \\
\hline
\end{tabular}

Skor maksimal $=125$

Berdasarkan hasil observasi aktivitas siswa dalam pelaksanaan pembelajaran matematika menggunakan model pembelajaran berbasis masalah pada materi sistem persamaan linear dua variabel, pada pertemuan pertama persentase keaktifan siswa berdasarkan lembar observasi adalah 49,6\% yang berarti bahwa keaktifan siswa pada pertemuan pertama berada dalam kategori sedang. Pada pertemuan pertama siswa masih belum terbiasa dengan diskusi kelompok. Mereka kurang menyadari tugas dan tanggung jawab dalam kelompok serta cenderung saling berharap kepada teman, sehingga kerjasama dalam kelompok berjalan kurang baik. Selain itu, sebagian besar siswa belum mampu menemukan sendiri penyelesaian suatu masalah pada LKS dan tidak dapat menyimpulkan hasil diskusi pembelajaran. Hal ini terjadi karena ada beberapa tahapan yang tidak dilakukan oleh sebagian besar siswa, mengakibatkan siswa sulit menarik kesimpulan pada tiap akhir kegiatan pembelajaran. Oleh karena itu dalam pelaksanaan pembelajaran 
dengan model pembelajaran berbasis masalah guru harus bisa memastikan bahwa siswa melalui tahapan-tahapan pembelajaran dengan baik.

Akan tetapi, secara umum angka keaktifan siswa terus meningkat hampir di tiap pertemuan. Hal ini menunjukan bahwa siswa mulai terbiasa belajar secara berkelompok dengan menggunakan model pembelajaran berbasis masalah. Pencapaian langkah-langkah pembelajaran di awal pertemuan juga membantu mengarahkan cara berpikir siswa, sehingga

Tabel 7

Distribusi Frekuensi dan Klasifikasi Normalized Gain Kemampuan Berpikir Kreatif Matematis Siswa

\begin{tabular}{|c|c|c|c|}
\hline Normalized Gain & Klasifikasi & F & Frekuensi Relatif (\%) \\
\hline$N$-Gain $\geq 0,70$ & Tinggi & 3 & 8,82 \\
\hline $0,30 \leq N$-Gain $<0,70$ & Sedang & 5 & 14,71 \\
\hline$N$-Gain $<0,30$ & Rendah & 26 & 76,47 \\
\hline \multicolumn{2}{|c|}{ Jumlah } & $\mathbf{3 4}$ & $\mathbf{1 0 0}$ \\
\hline
\end{tabular}

Tabel di atas, menunjukkan nilai normalzed gain paling banyak terdapat pada klasifikasi yang "rendah" yakni pada interval $N$ Gain < 0,30 dengan jumlah siswa 26 orang dan terdapat berturut-turut 5 dan 3 orang siswa berada pada kategori sedang dan tinggi. Hal ini menunjukkan bahwa, lebih dari setengah jumlah siswa memiliki kualitas peningkatan kemampuan berpikir kreatif matematis yang

Tabel 8

Peningkatan Kemampuan Berpikir Kreatif Matematis Siswa

\begin{tabular}{|c|l|c|c|c|c|}
\hline \multirow{2}{*}{ No. } & \multirow{2}{*}{ Indikator Berpikir kreatif } & \multicolumn{2}{|c|}{ Nilai Rata-Rata } & \multirow{2}{*}{ Posttest-Pretest } & $\begin{array}{c}\text { Persentase } \\
\text { Peningkatan } \\
(\%)\end{array}$ \\
\cline { 3 - 5 } & & Pretest & Posttest & & 102,1 \\
\hline 1 & Kelancaran (Fluency) & 34,55 & 69,85 & 35,5 & 85,03 \\
\hline 2 & Keluwesan (Flexibility) & 14,7 & 27,2 & 12,5 & 2,38 \\
\hline 3 & Keaslian (Originality) & 61,76 & 63,23 & 1,47 & -23.81 \\
\hline 4 & Keterincian (Elaboration) & 46,32 & 35,29 & $-11,03$ & Berdasarkan hasil pengujian uji \\
\hline
\end{tabular}
kemampuan berpikir kreatif matematis siswa pada tiap-tiap indikator mengalami peningkatan kecuali pada indikator terakhir. Tabel 4.6 memperlihatkan bahwa peningkatan kemampuan berpikir kreatif matematis pada indikator kelancaran mencapai lebih dari seratus persen, yakini sebesar 102,1\%, keluwesan sebesar $85,03 \%$, keaslian sebesar $2,38 \%$, sedangkan pada indikator keterincian mengalalami penurunan sebesar $23,81 \%$. siswa dapat beradaptasi dengan model pembelajaran berbasis masalah. Hal ini dilihat pada pertemuan kedua sampai dengan pertemuan kelima. Berdasarkan data ini, dapat disimpulkan bahwa ditinjau dari tingkat keaktifan siswa yang diajar dengan model pembelajaran berbasis masalah terinterpretasi baik dengan rata-rata keaktifan mencapai $72,32 \%$.

Data hasil penelitian, menghasilkan data klasifikasi normalized gain yang disajikan pada tabel 7 berikut:

rendah, dengan persentase sebesar 76,47\%. adalah 0,16 sehingga termasuk dalam kategori rendah, dengan nilai normalized gain terbesar adalah 1 dan nilai normalized gain terkecil -0,6.

Peningkatan kemampuan berpikir kreatif matematis siswa setiap indikator disajikan pada tabel 8 berikut: Rerata nilai normalized gain yang diperoleh Chi Square berbantuan software microsoft excel, diperoleh nilai $x^{2}{ }_{\text {hitung }}=6,6$. Karena nilai $x^{2}{ }_{\text {hitung }}$ data $N$-Gain $=6,6<7,82=x^{2}{ }_{\text {tabel }}$ maka $\mathrm{H}_{0}$ diterima. Hal ini menunjukan bahwa data $N$-Gain yang diperoleh berasal dari populasi yang berdistribusi normal.

Setelah dilakukan uji prasyarat, diperoleh hasil bahwa nilai pretest dan posttest siswa berdistribusi normal. Oleh karena itu, data pretest dan posttest kemampuan berpikir kreatif 
matematis siswa diuji menggunakan uji t sampel berpasangan (paired sample t-test). Uji hipotesis merupakan langkah atau prosedur untuk menentukan apakah hipotesis diterima atau ditolak. Rumusan hipotesis yang diuji adalah:

Keterangan:

$$
\mathrm{H}_{0}: \mu_{d} \leq 0 \text { lawan } \mathrm{H}_{1}: \mu_{d}>0
$$

$\mu_{d}=$ rata-rata selisih kemampuan berpikir kreatif matematis siswa sebelum dan setelah diajar dengan model pembelajaran berbasis masalah.

Hipotesis yang diajukan dalam penelitian ini adalah:

$\mathrm{H}_{0} \quad$ : Tidak terdapat pengaruh yang signifikan model pembelajaran berbasis masalah terhadap kemampuan berpikir kreatif

Tabel 9 matematis siswa kelas VIII SMP Negeri 4 Kendari

$\mathrm{H}_{1}$ : Terdapat pengaruh yang signifikan model pembelajaran berbasis masalah terhadap kemampuan berpikir kreatif matematis siswa kelas VIII SMP Negeri 4 Kendari

Kriteria pengambilan keputusan uji $\mathrm{t}$ sampel berpasangan dengan bantuan SPSS adalah sebagai berikut.

1. Jika $\frac{\text { sig.(2-tailed })}{2} \geq 0,05, \mathrm{H}_{0}$ diterima.

2. Jika $\frac{\text { sig.(2-tailed })}{2}<0,05, \mathrm{H}_{0}$ ditolak.

Hasil uji $t$ tersebut disajikan dalam tabel berikut:

Hasil Analisis Statistik Uji Hipotesis (Uji-t) Data Pretest-Posttest Kemampuan Berpikir Kreatif Matematis Siswa

\begin{tabular}{|c|c|c|c|c|}
\hline $\boldsymbol{t}$ hitung & $\boldsymbol{t}$ tabel & $\boldsymbol{d} \boldsymbol{f}$ & Sig. (2-tailed) & Keputusan \\
\hline 3,104 & 1,692 & 33 & 0,004 & Tolak $\mathrm{H}_{0}$ \\
\hline
\end{tabular}

Berdasarkan tabel tersebut, jika dilihat dari uji $t$ dengan $d f=33$ dan signifikansi $\alpha=5 \%$ diperoleh $t_{\text {tabel }}=1,692$. Terlihat bahwa nilai $t$ hitung lebih besar dari nilai $t$ tabel. Karena $t_{\text {hit }}=3,104>1,692=t_{\text {tabel }}$ dan nilai $\frac{\text { sig.(2-tailed })}{2}$ lebih kecil dari $\alpha(\alpha=0,05)$ yakni $\left(\frac{\text { sig. }(2-\text { tailed })}{2}=0,002<0,05=\alpha\right)$, sehingga $\mathrm{H}_{0}$ ditolak. Karena $\mathrm{H}_{0}$ ditolak, maka dapat disimpulkan bahwa terdapat pengaruh yang signifikan model pembelajaran berbasis masalah terhadap kemampuan berpikir kreatif matematis siswa kelas VIII SMP Negeri 4 Kendari pada pokok bahasan sistem persamaan linear dua variabel dengan taraf kepercayaan 95 persen.

\section{Pembahasan}

Penelitian ini bertujuan untuk mengetahui pengaruh model pembelajaran berbasis masalah terhadap kemampuan berpikir kreatif matematis siswa kelas VIII SMP Negeri 4 Kendari. Pelaksanaan penelitian ini menggunakan satu kelas eksperimen dimana pada kelas tersebut diterapkan model pembelajaran berbasis masalah. Sebelum proses pembelajaran dimulai, siswa terlebih dahulu diberi soal pretest untuk memperoleh data awal kemampuan berpikir kreatif matematis mereka. Soal pretest tersebut dibuat berdasarkan materi yang telah mereka pelajari, yaitu persamaan linear satu variabel. Kemudian dibandingkan dengan data posttest setelah diberikan perlakuan berupa pembelajaran menggunakan model pembelajaran berbasis masalah pada materi sistem persamaan linear dua variabel. Masingmasing tes pretest maupun posttest disusun berdasarkan indikator berpikir kreatif yaitu kelancaran (fluency), keluwesan (flexible), keaslian (originality) dan keterincian (elaboration).

Penelitian ini dilakukan dalam tujuh kali pertemuan, dengan lima kali pertemuan digunakan untuk proses pembelajaran dan dua kali pertemuan digunakan untuk tes kemampuan berpikir kreatif matematis siswa berupa pemberian pretest dan posttest. Alokasi waktu pembelajaran matematika wajib pada tiap pekan adalah 5 jam pelajaran. Sedangkan untuk tiap pertemuan alokasi waktunya berbeda, yaitu $3 \times$ 40 menit dan $2 \times 40$ menit. Pada saat pelaksanaan pretest dan posttest diberikan alokasi waktu masing - masing $3 \times 40$ menit (120 menit).

Model pembelajaran yang diterapkan pada kelas eksperimen adalah pembelajaran berbasis masalah yang memiliki lima tahap pembelajaran yaitu: orientasi siswa pada masalah, mengorganisasikan siswa untuk belajar, membimbing penyelidikan individual atau kelompok, mengembangkan dan menyajikan hasil karya, dan menganalisis dan 
mengevaluasi pemecahan masalah. Tahap-tahap tersebut menekankan kepada siswa agar mampu menyelesaikan suatu masalah dengan kemampuan berpikirnya sendiri, sehingga siswa jadi terlatih untuk mengembangkan kemampuan berpikir kreatif matematis mereka dalam memecahkan masalah matematika.

Proses pembelajaran dimulai dengan kegiatan pendahuluan berupa pemberian apersepsi, dilanjutkan dengan pemberian contoh masalah kontekstual yang berhubungan dengan materi sistem persamaan linear dua variabel. Kemudian guru membagi siswa ke dalam 8 kelompok belajar yang masing-masing terdiri atas 4-5 siswa berkemampuan heterogen. Setiap kelompok diberikan bahan ajar dan LKS. Pada tahap ini, apabila ada siswa yang bertanya maka guru akan berperan untuk mengarahkan dan membimbing siswa melalui penjelasan atau pertanyaan yang mengarah pada penyelesaian masalah. Setelah setiap kelompok menyelesaikan permasalahan dari LKS sesuai dengan waktu yang telah ditetapkan, beberapa siswa dipilih sebagai perwakilan dari kelompoknya untuk mempresentasikan hasil diskusi kelompok mereka kemudian ditanggapi oleh kelompok lain. Guru berperan memandu jalannya diskusi, meluruskan jika ada jawaban siswa yang keliru dan membantu siswa dalam mengambil kesimpulan jawaban yang benar dari hasil pemecahan masalah yang dibuat masingmasing kelompok. Pada akhir pertemuan, guru bersama siswa melakukan refleksi lalu guru akan membimbing siswa menyimpulkan materi yang telah dipelajari.

Berdasarkan lembar observasi, persentase pengelolaan pembelajaran oleh guru tidak pernah mencapai $100 \%$ dalam lima kali pertemuan. Hal Ini menandakan bahwa penerapan model pembelajaran berbasis masalah bukanlah hal mudah terutama bagi siswa. Pada pelaksanaan pembelajaran, ada langkah-langkah yang direncanakan tidak dapat dilaksanakan dengan maksimal pula tidak jarang soal yang dihadapi siswa tidak dapat diselesaikan dengan baik. Hal ini disebabkan oleh kurang mampunya siswa dalam menyelesaikan masalah-masalah yang membutuhkan kemampuan berpikir kreatif matematis. Apabila siswa kesulitan menyelesaikan masalah sampai mengalami kekeliruan atau bahkan sama sekali tidak tahu, guru menjelaskan proses penyelesaian masalah di papan tulis.
Pada pertemuan pertama pula peneliti mengalami hambatan dalam pelaksanaan pembelajaran karena siswa masih belum terbiasa dengan model pembelajaran yang baru diterima. Pada saat pembagian kelompok ada beberapa siswa yang menimbulkan suasana gaduh lantaran mereka belum terbiasa beradaptasi dengan kelompoknya, sehingga proses ini cukup menyita waktu pembelajaran. Siswa yang tidak terbiasa dalam diskusi kelompok cenderung tidak antusias dan kurang kooperatif dalam pembelajaran ini. Siswa masih membutuhkan waktu untuk menyesuaikan diri dengan pembelajaran yang baru diterapkan di kelas, sehingga ada beberapa kelompok yang masih sulit untuk berdiskusi dalam hal menyelesaikan masalah yang terdapat pada LKS. Sebagian besar juga belum percaya diri dalam mengeluarkan pendapat ataupun mengeluarkan pertanyaan, serta guru juga masih menyesuaikan diri dengan kondisi kelas. Hal ini mengakibatkan proses penyerapan materi pembelajaran oleh siswa kurang maksimal.

Pada pertemuan kedua dan pertemuanpertemuan berikutnya, proses pembelajaran berjalan dengan baik dan lancar. Siswa juga mulai memahami setiap tahap dalam model pembelajaran berbasis masalah yang diterapkan di kelas. Hal ini didukung dengan persentase ketercapaian aspek yang diamati yang secara keseluruhan meningkat dari tiap pertemuan dimana siswa telah menunjukan sikap antusias dalam pembelajaran dan mulai merasa bertanggung jawab dalam menyelesaikan masalah pada LKS yang diberikan. Siswa yang tadinya membutuhkan pengarahan guru dalam memberikan kesimpulan juga mulai mampu memberikan kesimpulan secara mandiri meski belum sepenuhnya.

Berdasarkan hasil observasi aktivitas guru dalam pelaksanaan pembelajaran dapat dikatakan bahwa pencapaian keterlaksanaan pembelajaran tergolong berhasil. Adapun hasil observasi keaktifan siswa, dapat dikatakan bahwa pencapaian keterlaksanaan pembelajaran ditiap pertemuan terus meningkat dan menunjukkan tanda-tanda siswa memenuhi kriteria kompetensi inti yang diinginkan.

Setelah proses pembelajaran selesai, pada pertemuan ke tujuh diberikan posttest. Kemudian, data hasil posttest tersebut diolah menggunakan SPSS bersama data pretest untuk menguji apakah model pembelajaran berbasis masalah memberikan pengaruh pada 
kemampuan berpikir kreatif matematis siswa kelas VIII SMP Negeri 4 Kendari.

Berdasarkan hasil analisis deskriptif, terlihat bahwa terdapat peningkatan kemampuan berpikir kreatif matematis siswa setelah diajar dengan menggunakan model pembelajaran berbasis masalah. Hal ini dapat terlihat dari nilai rata-rata pretest, posttest dan $N$-Gain.

Hasil analisis menunjukan bahwa model pembelajaran berbasis masalah memberikan pengaruh pada kemampuan berpikir kreatif matematis siswa. Secara akumulatif, terdapat 11 siswa yang mempunyai nilai dengan kriteria "kreatif" dan "sangat kreatif" setelah diajar dengan menggunakan model pembelajaran berbasis masalah. Sedangkan sebelumnya, dengan kriteria yang sama hanya ada 4 siswa saja dan siswa lebih banyak berada pada kriteria "cukup kreatif" yakni 10 orang siswa.

Berdasarkan rata-rata pencapaian kemampuan berpikir kreatif siswa perindikator sebelum diajar menggunakan model pembelajaran berbasis masalah, nilai rata-rata siswa secara berturut-turut pada indikator berpikir lancar, berpikir luwes berpikir asli dan berpikir merinci masing-masing 34,55, 14,7, 61,76, 46,32. Adapun setelah diajar menggunakan model pembelajaran berbasis masalah secara berturut-turut kemampuan berpikir lancar, berpikir luwes, berpikir asli dan berpikir merinci menjadi 69,85, 27,2, 63,23, dan 35,29 . Data ini menunjukkan bahwa setelah siswa diajar menggunakan model pembelajaran berbasis masalah, hampir seluruh indikator berpikir kreatif siswa meningkat. Peningkatan terbesar terjadi pada indikator berpikir lancar dengan selisih sebanyak 35,5 kemudian selisih kemampuan berpikir luwes dan berpikir asli berturut-turut yakni 12,5 dan 1,47. Akan tetapi pada indikator berpikir rinci justru mengalami penurunun sebesar $23,81 \%$. Hal ini diakibatkan karena mayoritas siswa merasa waktu pengerjaan soal yang diberikan tidak cukup, mulai jenuh untuk menyelesaikan soal terakhir yang memuat indikator berpikir rinci dan sebagian siswa masih belum sepenuhnya memahami cara menyelesaikannya.

Peneliti mengamati terdapat perbedaan pada sikap siswa sebelum dan setelah penerapan model pembelajaran berbasis masalah. Siswa semakin antusias dalam pembelajaran. Hal ini memberikan dampak positif pada keaktifan siswa di kelas. Dimana siswa cenderung makin aktif bertanya di pertemuan-pertemuan terakhir pembelajaran dibandingkan di pertemuanpertemuan awal dimana siswa cenderung pasif. Hal ini sangat membantu guru selama proses pembelajaran berlangsung. Siswa tidak begitu menunggu penjelasan dari guru, siswa berusaha untuk mencari penyelesaian dari soal atau masalah yang diberikan melalui informasi yang diperoleh dari buku maupun bahan ajar. Sehingga berdampak pada keampuan berpikir kreatifnya. Khususnya pada indikator berpikir lancar (fluently). Hal ini pula sesuai dengan pendapat Johnson (Moma, 2015: 28) yang menyatakan bahwa berpikir kreatif melibatkan aktivitas-aktivitas seperti mengajukan pertanyaan, mempertimbangkan informasiinformasi baru dan ide-ide yang tidak biasanya dengan suatu pemikiran terbuka, membuat hubungan-hubungan, khususnya antara sesuatu yang serupa, mengaitkan satu dengan yang lainnya dengan bebas, menerapkan imajinasi pada setiap situasi yang membangkitkan ide baru dan berbeda, dan memperhatikan intuisi.

Secara deskriptif, dapat diketahui bahwa terdapat peningkatan kemampuan berpikir kreatif matematis siswa setelah diajar dengan menggunakan model pembelajaran berbasis masalah. Agar lebih jelas dalam melihat pengaruh model pembelajaran berbasis masalah terhadap kemampuan berpikir kreatif matematis siswa, maka dilakukan uji hipotesis dengan menggunakan uji-t sampel berpasangan. Sebelum dilakukan uji hipotesis, terlebih dahulu dilakukan uji normalitas data $N$-Gain. Berdasarkan uji normalitas data menggunakan uji Chi Square dengan bantuan microsoft excel diperoleh bahwa data berasal dari populasi yang berdistribusi normal.

Berdasarkan hasil uji hipotesis data posttest-pretest kemampuan berpikir kreatif matematis siswa diperoleh bahwa terdapat pengaruh yang signifikan model pembelajaran berbasis masalah terhadap kemampuan berpikir kreatif matematis siswa kelas VIII SMP Negeri 4 Kendari.

\section{Simpulan dan Saran}

\section{Simpulan}

Berdasarkan hasil penelitian dan pembahasan yang telah dipaparkan pada bab 
sebelumnya, dapat disimpulkan beberapa hal berikut:

1. Kemampuan berpikir kreatif matematis siswa sebelum diajar dengan model pembelajaran berbasis masalah memiliki nilai rata - rata 39,01. Varians dan std. deviasi masing-masing sebesar 310,13 dan 17,61. Berdasarkan analisis data, tidak terdapat siswa yang berada pada kategori sangat kreatif, sedangkan persentase jumlah siswa yang berada pada kategori kreatif sebanyak $11,8 \%$, cukup kreatif sebanyak $41,2 \%$, kurang kreatif sebanyak $26,5 \%$ dan tidak kreatif sebanyak $20,6 \%$.

2. Kemampuan berpikir kreatif matematis siswa setelah diajar dengan model pembelajaran berbasis masalah memiliki nilai rata - rata 48,86. Varians dan std. deviasi masing-masing sebesar 533,33 dan 23,09. Hal ini menunjukkan kemampuan berpikir kreatif matematis siswa lebih beragam dari sebelum diterapkan model pembelajaran berbasis masalah. Berdasarkan analisis data setelah diajar dengan model pembelajaran berbasis masalah, terdapat $14,7 \%$ siswa dengan kategori sangat kreatif, sedangkan persentase jumlah siswa yang berada pada kategori kreatif sebanyak 17,6\%, cukup kreatif sebanyak 29,4\%, kurang kreatif sebanyak $23,5 \%$ dan tidak kreatif sebanyak $14,7 \%$.

3. Berdasarkan hasil analisis deskripitif dan inferensial, menunjukkan bahwa terjadi peningkatan kemampuan berpikir kreatif matematis siswa setelah diajar dengan menggunakan model pembelajaran berbasis masalah dengan peningkatan normalized gain berkategori rendah. Sehingga dapat dikatakan bahwa terdapat pengaruh yang signifikan model pembelajaran berbasis masalah terhadap kemampuan berpikir kreatif matematis siswa kelas VIII SMP Negeri 4 Kendari.

\section{Saran}

Berdasarkan hasil yang diperoleh dari penelitian ini, maka peneliti mengemukakan beberapa saran, yaitu:

1. Bagi guru model pembelajaran berbasis masalah dapat menjadi variasi pembelajaran di sekolah karena dapat meningkatkan kemampuan berpikir kreatif matematis yang merupakan salah satu kemampuan berpikir tingkat tinggi/HOTS (hing ordered thinking skills) yang termuat dalam kurikulum K13 serta ujian nasional.

2. Dengan adanya beberapa keterbatasan dalam penelitian ini, sebaiknya dilakukan penelitian yang lebih lanjut untuk meneliti tentang pembelajaran dengan model pembelajaran berbasis masalah pada pokok bahasan yang cocok atau pada jenjang sekolah yang berbeda.

3. Sangat penting bagi guru mampu mengelolah kelas dengan baik selama pelaksanaan pembelajaran dengan model pembelajaran berbasis masalah karena pada awal pembelajaran siswa mungkin akan kesulitan atau bahkan kurang kooperatif dalam pelaksanaan pembelajaran.

\section{Daftar Pustaka}

Hendriana, Rohaeti, dan Sumarmo. (2017). Hard Skills dan Soft Skills Matematik Siswa. Bandung. Refika Aditama.

Herman, Tatang. (2007). Pembelajaran Berbasis Masalah Untuk Meningkatkan Kemampuan Berpikir Matematis Tingkat tinggi Siswa Menengah Pertama. Jurnal Educationist. 1 (1), 48.

Lambertus, Arapu, \& Patih. (2013). Penerapan Pendekatan Open-Ended Untuk Meningkatkan Kemampuan Berpikir Kreatif Matematik Siswa SMP. Jurnal Pendidikan Matematika. 4 (1), 74.

Moma, La. (2015). Pengembangan Instrumen Kemampuan Berpikir Kreatif Matematis untuk Siswa SMP. Jurnal Matematika dan Pendidikan Matematika. 4 (1), 28.

Permana, Yanto dan Sumarmo, Utari. (2017). Mengambangkan Kemampuan Penalaran dan Koneksi Matematik Siswa SMA Melalui Model Pembelajaran Bebasis Masalah. Jurnal Educationist. 1 (2), 118.

Ruseffendi, E.T. (1979). Pengajaran Matematika Modern untuk Orang Tua Murid, Guru, dan SPG. Bandung. Tarsito.

Rusman. (2014). Model-Model Pembelajaran Mengembangkan Profesionalisme Guru Edisi Kedua. Jakarta. Rajagrafindo Persada.

Saefudin, A, A. (2012). Pengembangan Kemampuan Berpikir Kreatif Siswa 
Dalam Pembelajaran Matematika dengan Pendekatan Pendidikan Matematika Realistik Indonesia (PMRI). Jurnal AlBidayah. 4 (1), 40.

Sanjaya, Wina. (2007). Pembelajaran dalam Implementasi Kurikulum Berbasis Kompetensi. Jakarta. Kencana Media Grup.

Shoimin, Aris. (2014). Model Pembelajaran Inovatif dalam Kurikulum 2013. Yogyakarta. Ar-ruzz Media.

Sucipto. (2017). Pengembangan Keterampilan Berpikir Tingkat Tinggi dengan Menggunakan Strategi Metakognitif Model Pembelajaran Problem Based Learning. Jurnal Pendidikan. 2 (1), 64 dan 68

Suprihatiningrum, Jamil. (2016). Strategi Pembelajaran: Teori dan Aplikasinya. Yogyakarta. Ar-Ruzz Media.

Wahyuningsih, S, T. (2012). Pengaruh Pembelajaran Berbasis Masalah Berbantuan Media Pembelajaran Pohon Matematika Terhadap Kemampuan Berpikir Kreatif Matematik Peserta Didik Sekolah Menengah Pertama. Skripsi FMIPA Universitas Negeri Semarang: Semarang.

Wibawa, K, A. (2016). Defragmenting Struktur Berpikir Pseudo dalam Memecahkan Masalah Matematika. Yogyakarta. Deepublish. 